\title{
Improving Technology of Biscuit Semi-Finished Products Using Pumpkin Derived Products
}

\author{
Timoshenkova Irina Alekseevna \\ Peter the Great St. Petersburg Polytechnic University \\ St. Petersburg, Russia \\ itimoshenkova@spbstu.ru
}

Bernavskaya Maya Vladimirovna

Peter the Great St. Petersburg Polytechnic University

St. Petersburg, Russia

bernavskaya@mail.ru

\author{
Moscvicheva Elena Vladimirovna \\ Peter the Great St. Petersburg Polytechnic University \\ St. Petersburg, Russia \\ moskvicheva_ev@spbstu.ru \\ Chernikova Dariya Alekseevna \\ Peter the Great St. Petersburg Polytechnic University \\ St. Petersburg, Russia \\ dasha511997@yandex.ru
}

\author{
Fedinishina Yekaterina Yurievna \\ Peter the Great St. Petersburg Polytechnic University \\ St. Petersburg, Russia \\ 71311@mail.ru
}

\begin{abstract}
A possibility and expediency of pumpkin seeds flour utilization for production of biscuit semi-finished product was studied; the influence of the flour on consumer properties of the product was investigated. Studies were conducted on organoleptic and physicochemical indicators of the finished biscuit semifinished products. Grounding on the implemented studies a new production technology of pumpkin seeds flour based biscuits was developed, shelf life, biological, and nutrition value were identified. It was established that the optimal ratio of pumpkin seeds flour and starch is $90.5 \pm 0.5 \%$ to $9.5 \pm 0.5 \%$. It was established that after consuming $100 \mathrm{~g}$ of the biscuit with a complete substitution of wheat flour to the gluten-free mixture $44 \%$ of daily need in magnesium, $50 \%$ - in selenium, $39 \%$ - in copper, $48 \%$ - in phosphorus, $46 \%$ - in manganese, $36 \%$ - in vitamin $\mathrm{B} 9$, and $36 \%$ in linoleic acid is satisfied.
\end{abstract}

Keywords- pumpkin seeds flour, biscuit, nutrition value, biological value

\section{INTRODUCTION}

Flour confectionery remains an integral part of any cuisine and plays a great role in nutrition of humanity.

Amongst the whole variety of baked semi-finished products intended for cake production, biscuits characterized by the puffy and light structure gained the most distribution. However, from the point of a nutrition value, biscuits cooked according to traditional recipes lack stability in their chemical contents. The ratio of the main nutritional substances (protein, lipids, and assimilable carbohydrates) in biscuit \#1 in a collection of flour confectionery and bun goods makes 1:0.75:5.85 [1]. Most flour confectionery is characterized by poor contents of protein, essential amino acids, macro- and microelements, vitamins, and other vital nutrients, as well as by a high caloric content. Within modern requirements on the part of consumers, flour confectionery does not need to be a vacuous calories carrier, but to provide a specific functionality.

A substantial part of food products is taken by products devoid of grain crop protein, which causes an autoimmune chronic Gee's disease [2].

The search for raw materials, which could allow creating quality gluten-free products possessing a balanced chemical content and high nutrition value, comes to the forefront. Ways of production of gluten-free confectionery were developed with the use of various flour types, such as triticale, rice, buckwheat, corn, fat-free flour from grape, watermelon, thistle fruit seeds; vegetable, fruit and vegetable and berry purees, pastes and powders; grain and groats conversion products [3-14]. Currently pumpkin flour, which is produced during the processing of its seeds, is of special interest. Chemical contents of pumpkin seeds are characterized by a high composition of vitamins, macro- and microelements, essential amino acids and polyunsaturated fat acids.

The aim of this paper is to develop a technology for a biscuit semi-finished product with a complete substitution of wheat flour by pumpkin seeds flour.

Due to the set aim, the following tasks were identified:

- to investigate technological characteristics of pumpkin seeds flour;

- to investigate organoleptic and physicochemical indicators of biscuit baked products with a complete substitution of wheat flour to pumpkin seeds flour with 
varying ratio of starch from a dry mixture mass and to identify optimal ratio of pumpkin seeds flour and starch from dry mixture mass;

- to develop a technology of a biscuit with a complete substitution of wheat flour to a gluten-free mixture;

- to conduct a complex evaluation of the quality of new biscuit baked products.

- Pumpkin seeds flour and biscuit of recipe \#1 according to a collection of flour confectionery and bun products [15] were chosen as the object of investigation.

\section{METHODS OF INVESTIGATION}

Sampling and their preparation for analysis were conducted in compliance with State Standard 5904; pumpkin seeds flour humidity - State Standard 9404; autolytic activity - State Standard 27495; amount and quality of gluten - State Standard 27839; acidity of the flour - State Standard 27493; mass fraction of moisture in biscuit semi-finished products - State Standard 21094; organoleptic indicators - State Standard 50763; porosity of biscuit semi-finished products - State Standard 5669.

According to commonly known methods, the following physicochemical indicators were identified:

- Gelation temperature - by heating the flour suspension to the temperature of $55-95^{\circ} \mathrm{C}$ with a $10^{\circ} \mathrm{C}$ step and subsequent centrifuging of a cooled sample during 10 minutes with 3000 revolutions per minute speed.

- Density of baked gluten-free products - as a ratio of mass to the volume of a baked semi-finished product's fragment.

- Baking losses of gluten-free products - by a ratio of difference between test preparation mass and the baked semi-finished product to test preparation mass.

- Swelling capacity of crumb of baked gluten-free products - according to a method developed by SaintPetersburg State Science and Research Institute of Baking Industry.

- Water activity of baked gluten-free products using a device Aqulab Pawkit.

A generalized organoleptic indicator was identified by (1):

$$
\sum_{\mathrm{i}=1}^{\mathrm{n}} \mathrm{p}_{\mathrm{i}} \mathrm{k}_{\mathrm{i}}
$$

where $p_{i}$ is a value of $i$ organoleptic indicator;

$\mathrm{k}_{\mathrm{i}}$ is a value of ponderability coefficient of $\mathrm{i}$ organoleptic indicator.

TABLE I. COEFFICIENTS OF PONDERABILITY OF ORGANOLEPTIC INDICATORS OF GLUTEN-FREE BISCUIT SEMI-FINISHED PRODUCTS

\begin{tabular}{|c|c|c|c|c|c|}
\hline $\begin{array}{c}\text { Organoleptic } \\
\text { indicator }\end{array}$ & $\begin{array}{c}\text { Appear } \\
\text { ance }\end{array}$ & Color & Texture & Aroma & Taste \\
\hline $\begin{array}{c}\text { Ponderability } \\
\text { coefficient }\end{array}$ & 5.0 & 2.0 & 4.0 & 4.0 & 5.0 \\
\hline
\end{tabular}

TABLE II. ORGANOLEPTIC EVALUTION CRITERIA

\begin{tabular}{|c|c|c|c|c|c|}
\hline \multirow{2}{*}{$\begin{array}{l}\text { Organ } \\
\text { oleptic } \\
\text { indica } \\
\text { tor }\end{array}$} & \multicolumn{5}{|c|}{ Verbal characteristic of points } \\
\hline & 5 & 4 & 3 & 2 & 1 \\
\hline $\begin{array}{l}\text { Appea } \\
\text { rance }\end{array}$ & $\begin{array}{l}\text { Correct form, } \\
\text { complies with } \\
\text { form in which } \\
\text { baked } \\
\text { products were } \\
\text { produced } \\
\text { earlier, with } \\
\text { somewhat } \\
\text { salient upper } \\
\text { crust without } \\
\text { cracks and } \\
\text { tears, smooth } \\
\text { surface, thin } \\
\text { and soft upper } \\
\text { crust }\end{array}$ & $\begin{array}{l}\text { Correct } \\
\text { form, } \\
\text { insignifi } \\
\text { cant } \\
\text { tears, } \\
\text { insuffici } \\
\text { ent } \\
\text { extent of } \\
\text { rise, } \\
\text { smooth } \\
\text { surface, } \\
\text { thin } \\
\text { upper } \\
\text { crust }\end{array}$ & $\begin{array}{l}\text { Correct } \\
\text { form, } \\
\text { with } \\
\text { small } \\
\text { defects } \\
\text { of } \\
\text { surface } \\
\text { (tears, } \\
\text { cracks, } \\
\text { hollows } \\
\text { ), } \\
\text { thicker } \\
\text { upper } \\
\text { crust }\end{array}$ & $\begin{array}{l}\text { Incorrec } \\
t \text { form of } \\
\text { the } \\
\text { biscuit, } \\
\text { flat } \\
\text { upper } \\
\text { crust } \\
\text { with } \\
\text { significa } \\
\text { nt tears } \\
\text { and } \\
\text { cracks } \\
\text { and } \\
\text { hollows, } \\
\text { thick } \\
\text { crust }\end{array}$ & $\begin{array}{l}\text { Incorrect } \\
\text { form of } \\
\text { the } \\
\text { biscuit, } \\
\text { absence } \\
\text { of rise, } \\
\text { thick and } \\
\text { flat crust } \\
\text { with } \\
\text { significa } \\
\text { nt tears } \\
\text { and } \\
\text { cracks }\end{array}$ \\
\hline Color & $\begin{array}{l}\text { Light-brown } \\
\text { crusts, light } \\
\text { green crumb } \\
\text { that complies } \\
\text { with the color } \\
\text { of pumpkin } \\
\text { seeds, even } \\
\text { color }\end{array}$ & $\begin{array}{l}\text { Light- } \\
\text { brown } \\
\text { crusts, } \\
\text { light } \\
\text { green or } \\
\text { yellowis } \\
\text { h crumb, } \\
\text { even } \\
\text { color }\end{array}$ & $\begin{array}{l}\text { Dark- } \\
\text { brown } \\
\text { crusts, } \\
\text { yellowi } \\
\text { sh } \\
\text { crumb, } \\
\text { even } \\
\text { color }\end{array}$ & $\begin{array}{l}\text { Dark- } \\
\text { brown } \\
\text { crusts } \\
\text { and } \\
\text { crumb, } \\
\text { uneven } \\
\text { color }\end{array}$ & $\begin{array}{l}\text { Dark } \\
\text { color of } \\
\text { crusts } \\
\text { and } \\
\text { crumb, } \\
\text { uneven } \\
\text { color, } \\
\text { burned } \\
\text { parts }\end{array}$ \\
\hline $\begin{array}{l}\text { Textur } \\
\mathrm{e}\end{array}$ & $\begin{array}{l}\text { Well- } \\
\text { developed } \\
\text { porosity, even } \\
\text { pore } \\
\text { distribution, } \\
\text { soft and elastic } \\
\text { crumb }\end{array}$ & $\begin{array}{l}\text { Uneven } \\
\text { pore } \\
\text { distributi } \\
\text { on, soft } \\
\text { and } \\
\text { elastic } \\
\text { crumb }\end{array}$ & $\begin{array}{l}\text { Weakly } \\
\text { express } \\
\text { ed } \\
\text { porosity } \\
\text {, } \\
\text { unevenl } \\
\text { y } \\
\text { distribu } \\
\text { ted } \\
\text { pores, } \\
\text { friable } \\
\text { crumb }\end{array}$ & $\begin{array}{l}\text { Not } \\
\text { expresse } \\
\text { d } \\
\text { porosity, } \\
\text { quite } \\
\text { firm } \\
\text { crumb }\end{array}$ & $\begin{array}{l}\text { Nonporo } \\
\text { us } \\
\text { biscuit, } \\
\text { teared } \\
\text { crumb }\end{array}$ \\
\hline Aroma & $\begin{array}{l}\text { Well } \\
\text { expressed, } \\
\text { complies with } \\
\text { pumpkin seeds } \\
\text { smell, without } \\
\text { foreign hints }\end{array}$ & $\begin{array}{l}\text { Well } \\
\text { expresse } \\
\text { d, } \\
\text { complies } \\
\text { with } \\
\text { pumpkin } \\
\text { seeds } \\
\text { smell, } \\
\text { without } \\
\text { foreign } \\
\text { hints }\end{array}$ & $\begin{array}{l}\text { Typical } \\
\text { to the } \\
\text { type of } \\
\text { product } \\
\text { with a } \\
\text { small } \\
\text { hint of } \\
\text { pumpki } \\
\mathrm{n} \text { seeds } \\
\text { smell }\end{array}$ & $\begin{array}{l}\text { Not } \\
\text { expresse } \\
d, \\
\text { presence } \\
\text { of } \\
\text { foreign } \\
\text { smells }\end{array}$ & $\begin{array}{l}\text { Aroma } \\
\text { untypical } \\
\text { to the } \\
\text { studied } \\
\text { type of } \\
\text { products, } \\
\text { presence } \\
\text { of } \\
\text { foreign } \\
\text { hints }\end{array}$ \\
\hline Taste & $\begin{array}{l}\text { Well } \\
\text { expressed, } \\
\text { complies with } \\
\text { pumpkin seeds } \\
\text { smell, without } \\
\text { foreign tinges }\end{array}$ & $\begin{array}{l}\text { Well } \\
\text { expresse } \\
\text { d, } \\
\text { complies } \\
\text { with } \\
\text { pumpkin } \\
\text { seeds } \\
\text { smell, } \\
\text { without } \\
\text { foreign } \\
\text { tinges }\end{array}$ & $\begin{array}{l}\text { Weakly } \\
\text { express } \\
\text { ed, } \\
\text { presenc } \\
\text { e of } \\
\text { bitter } \\
\text { tinge }\end{array}$ & $\begin{array}{l}\text { Not } \\
\text { expresse } \\
\mathrm{d} \text {, } \\
\text { presence } \\
\text { of } \\
\text { foreign } \\
\text { tinges }\end{array}$ & $\begin{array}{l}\text { Taste } \\
\text { untypical } \\
\text { to the } \\
\text { studied } \\
\text { type of } \\
\text { products, } \\
\text { presence } \\
\text { of } \\
\text { foreign } \\
\text { tinges }\end{array}$ \\
\hline
\end{tabular}

\section{RESULTS AND DISCUSSIONS}

Results of investigation of physicochemical parameters are demonstrated in table III. 
Coefficients of ponderability were established depending on significance of an organoleptic indicator (table I). The sum of all the coefficients was set as 20 . This way, with a 5-point scale of organoleptic indicators evaluation, the maximum value of a generalized organoleptic indicator amounts to 100 .

Organoleptic analysis of gluten-free biscuit products was conducted according to a 5-point scale. For a comparative organoleptic evaluation, a system of indicators was developed which includes appearance, color, texture, aroma, and taste (table II).

Pumpkin seeds flour is a loose powder of a light-green color, no crunch is felt during chewing, which implies the absence of mineral admixture, taste and aroma typical for pumpkin seeds.

TABLE III. PHYSICOCHEMICAL INDICATORS OF PUMPKIN SEEDS FLOUR QUALITY

\begin{tabular}{|l|l|l|}
\hline Indicators & $\begin{array}{l}\text { Premium grade wheat } \\
\text { flour }\end{array}$ & $\begin{array}{l}\text { Pumpkin seeds } \\
\text { flour }\end{array}$ \\
\hline Humidity, \% & $14.5 \pm 0.2$ & $7.6 \pm 0.2$ \\
\hline Autolytic activity, \% & $30.0 \pm 0.5$ & $24.0 \pm 0.5$ \\
\hline Amount of gluten, \% & $83.0 \pm 0.1$ & - \\
\hline Acidity, ${ }^{\mathbf{o}} \mathrm{T}$ & $4.0 \pm 0.2$ & $22.6 \pm 0.2$ \\
\hline
\end{tabular}

The autolytic activity indicator of pumpkin seeds flour complies with the indicator of premium grade wheat flour. An increased acidity of pumpkin seeds flour ( 5 and a half time more than of wheat flour) is explained by the presence of a great amount of organic and polyunsaturated fat acids, which will contribute to intensification of a sucrose hydrolase process during biscuit dough formation.

Thus, pumpkin seeds flour does not possess baking properties of wheat flour; however, it may be recommended to use in confectionery industry as the main and additional component of gluten-free mixture, during creation of functional products, for flour confectionery products that do not require a high content of gluten like biscuit.

Gluten-free mixture based on pumpkin seeds flour and the method of adding eggs were taken as factors that influence quality of biscuit semi-finished products and especially porosity of the finished products.

Gluten-free mixture used for production of biscuit semifinished products consists of pumpkin seeds flour and starch.

Investigation of organoleptic indicators and humidity of biscuit semi-finished products was conducted based on glutenfree mixture samples varying ration of starch from 0 to $20 \%$ with a $2 \%$ step.

On the grounds of experimental data, regression equations were obtained characterizing dependency of generalized organoleptic indicator (Y1) (2) and humidity of biscuit semifinished products (Y2) (3) on starch content (x, ratio) in a gluten-free mixture.

$$
\begin{aligned}
& Y_{1}=\frac{1}{0,01+0,15 \mathrm{x}^{2}} \\
& \mathrm{Y}_{2}=\frac{1}{0,03+0,14 \mathrm{x}}
\end{aligned}
$$

Correlation coefficients of obtained regression equations are 0.86 and 0.99 correspondingly, which allows one to speak about functional dependency of generalized organoleptic indicator and humidity of biscuit semi-finished product on starch content in a gluten-free mixture. Determination coefficients of obtained regression equations are 0.75 and 0.98 correspondingly, corrected determination coefficients are 0.72 and 0.97 correspondingly which proves significance of the chosen factors.

Graphic interpretation of equations (2) and (3) are illustrated in Fig. 1 and Fig. 2.

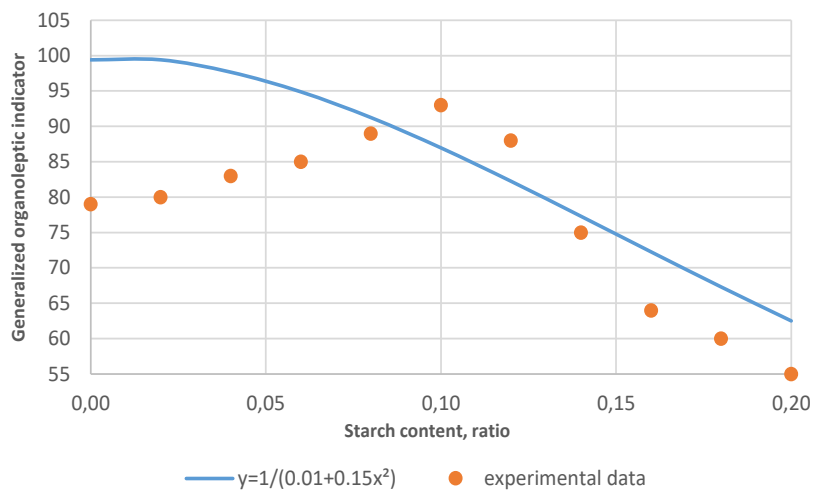

Fig. 1. Dependency graph of generalized organoleptic indicator of biscuit semi-finished products on starch content in gluten-free mixture

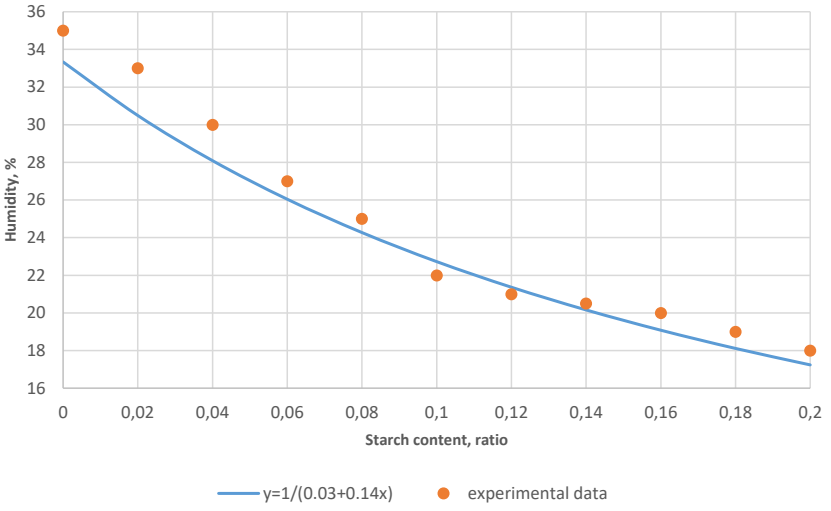

Fig. 2. Dependency graph of humidity of biscuit semi-finished products on starch content in gluten-free mixture

Analysis of revealed dependencies showed that the ratio of pumpkin seeds flour and starch $90.5 \pm 0.5 \%$ to $9.5 \pm 0.5 \%$ is close to optimal and provides satisfactory quality of biscuit semifinished products.

A sectional view of pumpkin seeds flour-based biscuit sample is demonstrated in Fig. 3. It is evident that the baked biscuit sample has a small rise and sank after baking, which implies weak stability of biscuit dough. 


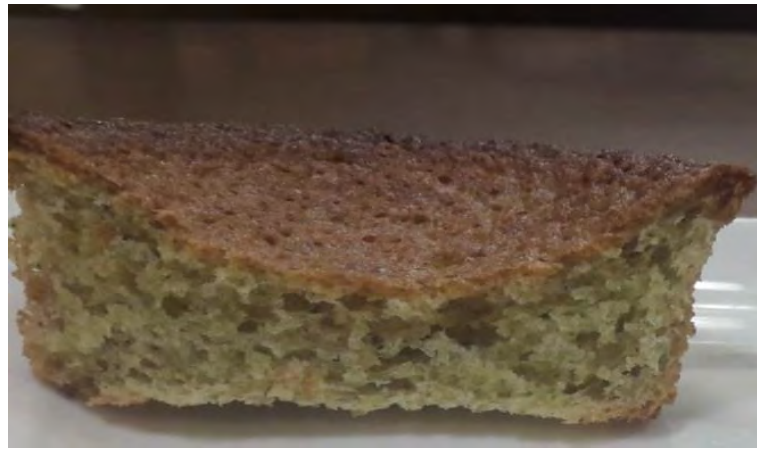

Fig. 3. Sectional view of gluten-free biscuit semi-finished product sample

In order to investigate the influence of methods of adding eggs on biscuit dough and quality of biscuit semi-finished products, they were added in the form of mélange (sample 1) and separately (sample 2). For separate addition, yolks were shaken up with $1 / 4$ of sugar, whereas whites where shaken up until the increase of the volume reached 6 times and then boiled with syrup under $120^{\circ} \mathrm{C}$. Then all the ingredients were mixed with flour regardless of the method of adding eggs. Flour is added directly before baking the semi-finished product. This relates to the fact that when increasing time period between mixing and baking, the biscuit dough foamy structure is destroyed which in turn leads to deterioration of baked product's quality.

The baked biscuit products were analyzed according to the main organoleptic (appearance, color, texture, aroma, taste) and physicochemical (humidity, porosity, density, swelling capacity of crumb, dough rise extent, baking losses) indicators.

Experimental data are shown in Fig. 4-10 and in table 4.

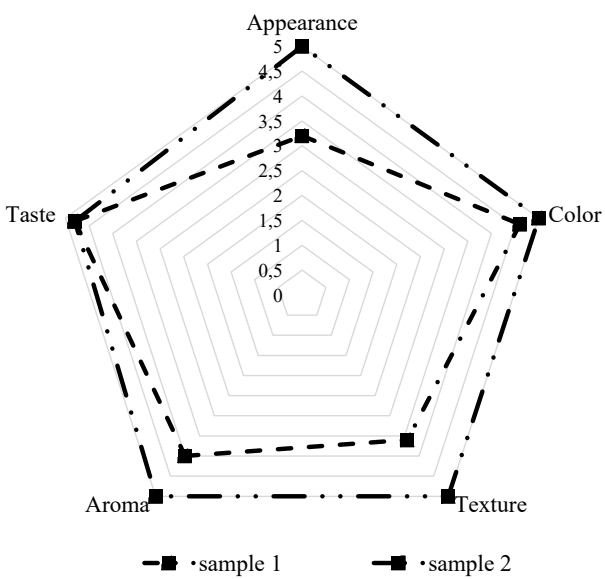

Fig. 4. Profilogram of dependency of point-based organoleptic evaluation on biscuit semi-finished product technology

Fig. 4 demonstrates that the biscuit made using a method of separate addition of eggs and boiling protein shows superiority over the sample made by traditional technology with the use of mélange by all the organoleptic indicators, which denotes its high quality.
Appearances of biscuit semi-finished products are illustrated in Fig. 5 a) and b).

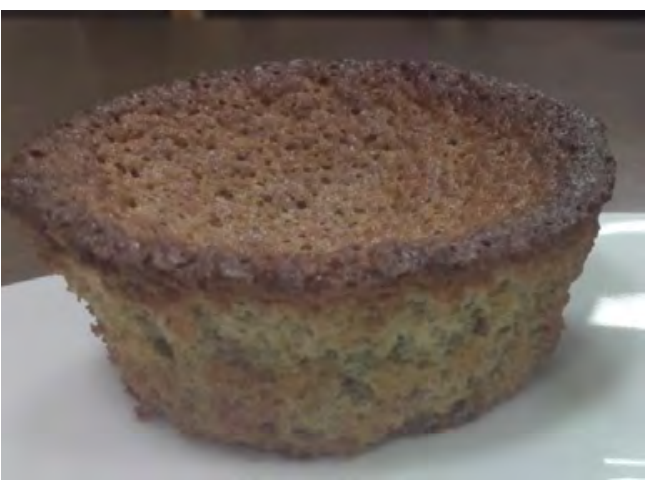

(a)

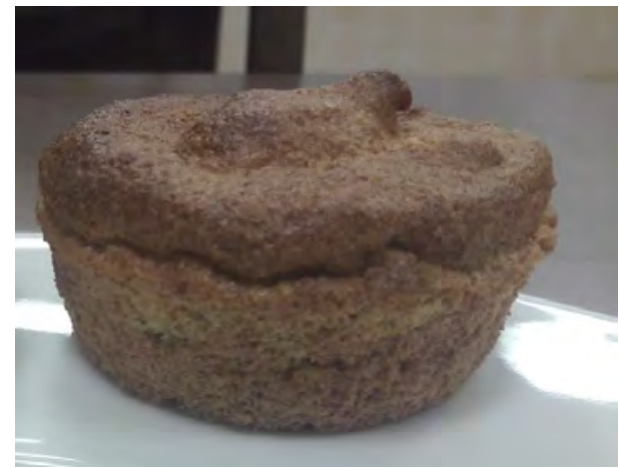

(b)

Fig. 5. Appearances of biscuit semi-finished products with use of mélange (a) and separate eggs addition (b)

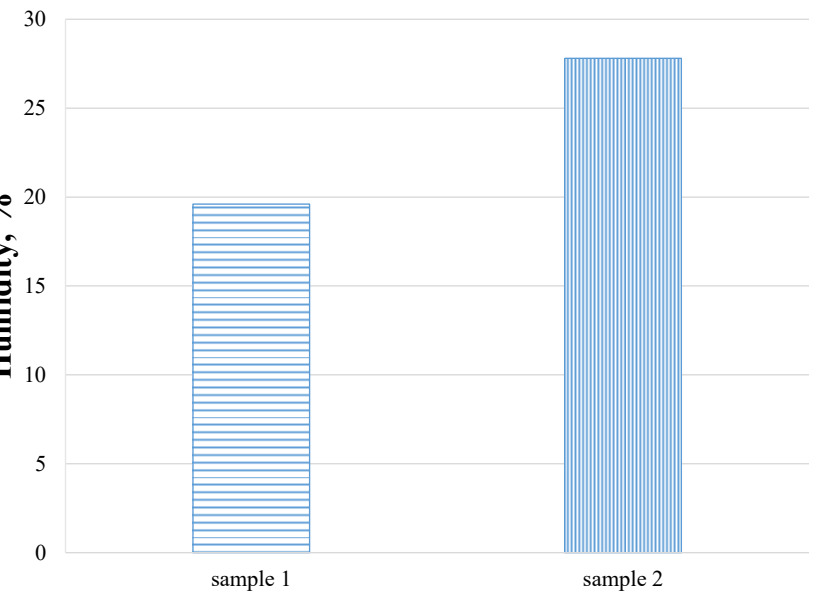

Fig. 6. Histogram of dependency of humidity on biscuit semi-finished product technology

The humidity indicator (Fig. 6) of biscuit semi-finished product, baked according to technology of separate addition of eggs and boiling protein with hot syrup, amounts to $27.8 \%$ and complies to standard humidity for biscuit from wheat flour stated in collection of flour confectionery and bun products which totals to $25.00 \pm 3.0 \%$ [15]. A low indicator of humidity of the first sample indicates its dry consistency and crumbliness. 


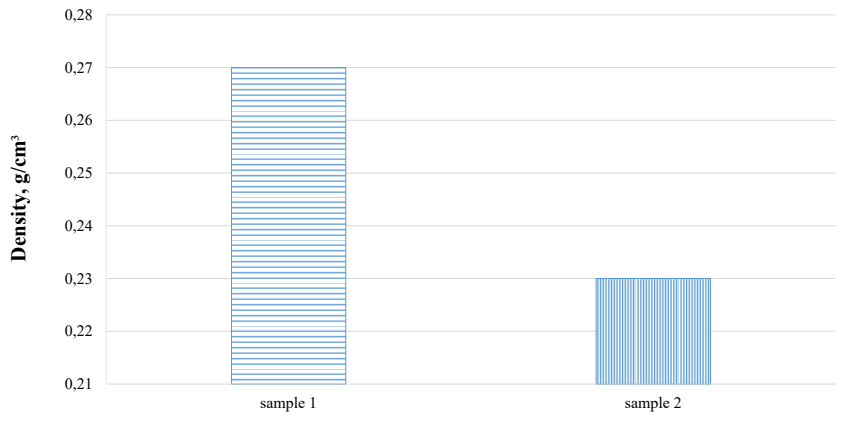

Fig. 7. Histogram of dependency of density on biscuit semi-finished product technology

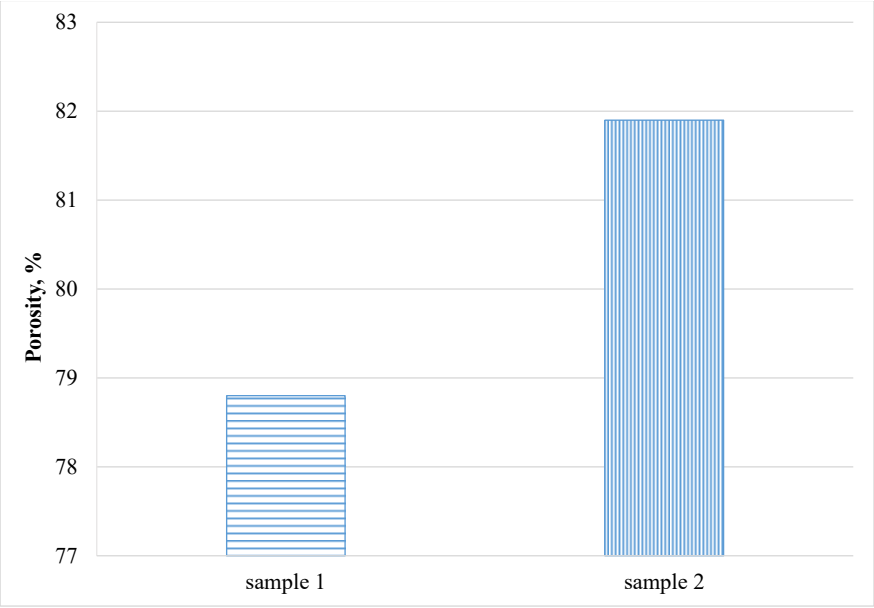

Fig. 8. Histogram of dependency of porosity on biscuit semi-finished product technology

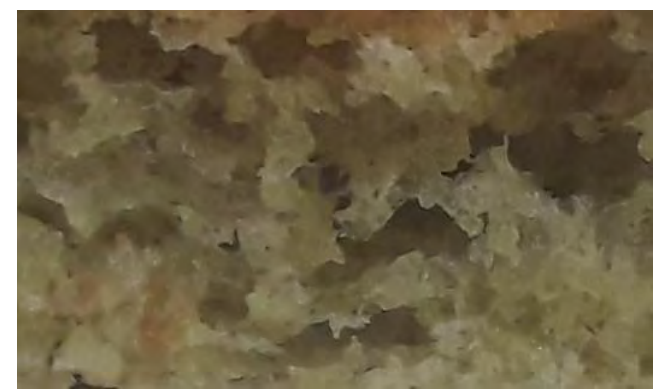

(a)

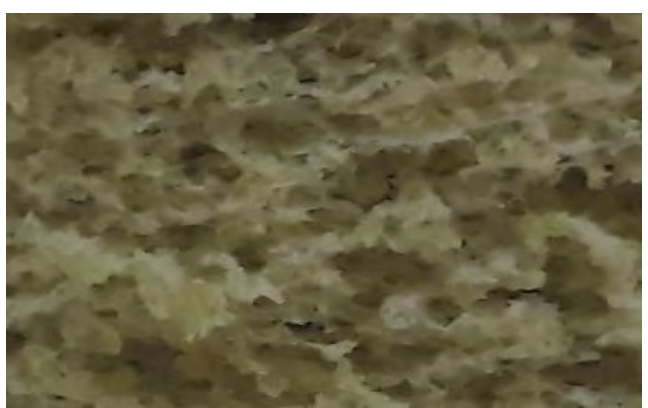

(b)

Fig. 9. Cross-section view of a biscuit semi-finished product from mélange (a) and with a separate addition of eggs (b)

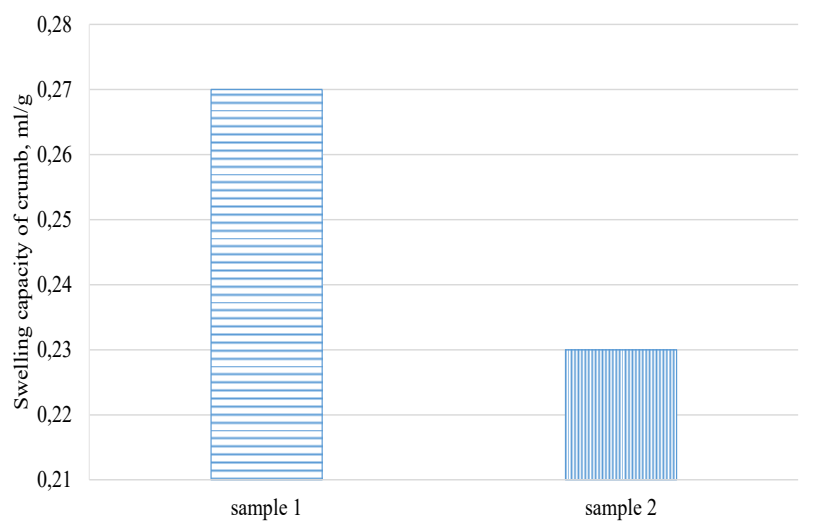

Fig. 10. Histogram of dependency of swelling capacity of crumb on biscuit semi-finished product technology

The second sample of the biscuit semi-finished product baked by a new technology possesses lower density and has an advantage over the first sample in porosity indicators as the method of separate addition of eggs and boiling protein with hot syrup under $120{ }^{\circ} \mathrm{C}$ stabilizes the foam and contributes to the even distribution of small pores, which can be seen in a crosssection view of two samples of biscuit semi-finished products in Fig. 9 a) and b).

The swelling capacity of crumb of thebiscuit semi-finished product with a separate addition of eggs (Fig. 10) is higher than that of the first sample. Therefore, the second biscuit sample will be easier to impregnate with syrup and will maintain its form better.

The biscuit dough rise extent and sinking indicators of biscuit semi-finished products are shown in table IV.

TABLE IV. DOUGH RISE EXTENT AND SINKING INDICATORS OF BISCUIT SEMI-FINISHED PRODUCTS

\begin{tabular}{|c|c|c|}
\hline $\begin{array}{c}\text { Biscuit semi-finished } \\
\text { product type } \\
\text { depending on a } \\
\text { technology }\end{array}$ & $\begin{array}{c}\text { Biscuit dough rise } \\
\text { extent, \% }\end{array}$ & $\begin{array}{c}\text { Sinking of biscuit } \\
\text { semi-finished } \\
\text { products, \% }\end{array}$ \\
\hline Sample \#1 & $17.2 \pm 0.2$ & $19.9 \pm 0.3$ \\
\hline Sample \#2 & $46.4 \pm 0.4$ & $12.9 \pm 0.2$ \\
\hline
\end{tabular}

The main reason for sinking is moisture evaporation and formation of the crust. Increase of sinking indicators leads to crust thickening and decrease of product output. Sinking indicator is lower than that of the second sample. The dough rise extent of sample \#2 is higher, as the separate addition of eggs and boiling shaken protein, 6 times bigger the volume with hot syrup, stabilizes the foam and the products become more finely-porous.

Stored gluten-free biscuit semi-finished products were evaluated according to the generalized organoleptic indicator, water activity and mass as well as organoleptic indicators grounding on which the shelf-life period of baked products can be revealed.

Organoleptic indicators of the second sample during storing were substantially superior over those of the first sample due to the finely porous and elastic structure of the biscuit. 
On the basis of experimental data, regression equations were obtained characterizing dependency of water activity indicator (Y3) (4) and mass (Y4) (5) on storing duration (days).

$$
\begin{gathered}
\mathrm{Y}_{3}=\sqrt{0,56+0,61 / \mathrm{x}} ; \\
\mathrm{Y}_{4}=26,18+3,2 / \mathrm{x} .
\end{gathered}
$$

Correlation coefficients of obtained regression equations are 0.994 and 0.992 correspondingly, which allows speaking about functional dependency of the water activity indicator and mass of the biscuit semi-finished product on storing duration. Determination coefficients of obtained regression equations are 0.985 and 0.983 .

Investigation results of water activity of baked biscuit semifinished products during storing are demonstrated in Fig. 11; changes in mass of biscuit semi-finished products - in Fig. 12.

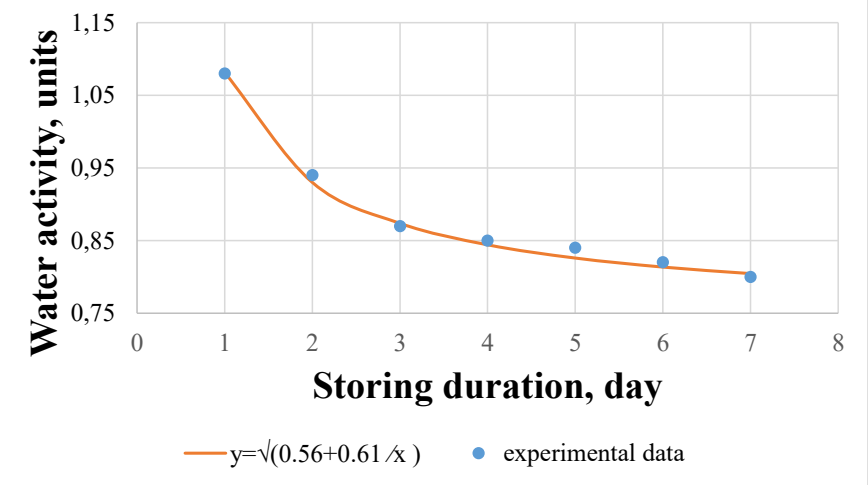

Fig. 11. Water activity of biscuit semi-finished products

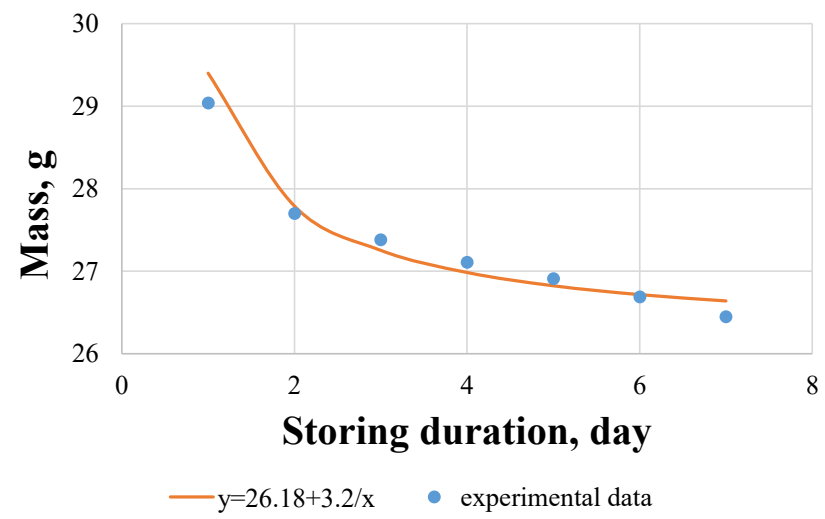

Fig. 12. Changes in mass of biscuit semi-finished products

Water activity of biscuit semi-finished products during storing decreases hyperbolically down to the value of 0.8 ; the mass of biscuit semi-finished product made with the method of separate addition of eggs and boiling protein with hot syrup insubstantially decreases after baking. At the same time, the process of staking related to retrogradation of starch is almost not observed; the products stays soft and elastic.

Results of calculations of amino acid score for biscuit semifinished products with pumpkin seeds flour are shown in table $\mathrm{V}$.
Biscuit semi-finished products based on pumpkin seeds flour satisfy the human need for tryptophan amino acid, the score of which equals $100 \%$. Limiting acids in the studied semifinished product are lysine and threonine.

TABLE V. AMINO ACID COMPOSITION AND SCORE FOR BISCUIT SEMIFINISHED PRODUCTS

\begin{tabular}{|c|c|c|c|}
\hline Amino acid & $\begin{array}{c}\text { Amino acid } \\
\text { content in } \\
\text { the ideal } \\
\text { protein, mg }\end{array}$ & $\begin{array}{l}\text { Amino acid } \\
\text { content in } \\
\text { the studied } \\
\text { protein, mg }\end{array}$ & $\begin{array}{c}\text { Amino acid } \\
\text { score, \% }\end{array}$ \\
\hline Isoleucine & 40 & 28 & 70 \\
\hline Lleucine & 70 & 47 & 67 \\
\hline Lysine & 55 & 31 & 56 \\
\hline Methionine+cysteine & 35 & 23 & 66 \\
\hline Phenylalanine+tyrosine & 60 & 53 & 88 \\
\hline Threonine & 40 & 23 & 58 \\
\hline Tryptophan & 10 & 10 & 100 \\
\hline Valine & 50 & 33 & 66 \\
\hline
\end{tabular}

TABLE VI. NUTRITIONAL VALUE OF BISCUIT SEMI-FINISHED PRODUCTS

\begin{tabular}{|l|c|}
\hline \multicolumn{1}{|c|}{ Indicator } & Biscuit semi-finished product \\
\hline Protein content, $\mathrm{g} / 100 \mathrm{~g}$ of product & 11 \\
\hline Lipid content, $\mathrm{g} / 100 \mathrm{~g}$ of product & 8 \\
\hline $\begin{array}{l}\text { Carbohydrate content, } \mathrm{g} / 100 \mathrm{~g} \text { of } \\
\text { product }\end{array}$ & 13 \\
\hline Energy value, $\mathrm{kcal}$ & 150 \\
\hline
\end{tabular}

TABLE VII. MINIRAL ELEMENTS, VITAMINS AND POLYUNSATURATED FAT

\begin{tabular}{|c|c|c|c|}
\hline Name & $\begin{array}{c}\text { Standard } \\
\text { daily rate, } \\
\text { mg }\end{array}$ & $\begin{array}{l}\text { Content in } \\
100 \mathrm{~g} \text { of } \\
\text { product, } \mathrm{mg}\end{array}$ & $\begin{array}{c}\text { Realization of } \\
\text { a standard } \\
\text { daily rate, } \%\end{array}$ \\
\hline \multicolumn{4}{|c|}{ Mineral elements } \\
\hline Magnesium & 400.00 & 177.92 & 44.48 \\
\hline Iron & 18.00 & 3.95 & 21.95 \\
\hline Zinc & 12.00 & 2.26 & 18.87 \\
\hline Selenium & 0.06 & 0.03 & 49.56 \\
\hline Copper & 10.00 & 0.39 & 38.95 \\
\hline Phosphorus & 800.00 & 386.35 & 48.29 \\
\hline Manganese & 2.00 & 0.93 & 46.40 \\
\hline Calcium & 1000.00 & 44.07 & 4.41 \\
\hline Potassium & 2500.00 & 308.17 & 12.33 \\
\hline Sodium & 1300.00 & 72.20 & 5.55 \\
\hline \multicolumn{4}{|c|}{ Vitamins } \\
\hline Vitamin A & 0.90 & 0.12 & 12.80 \\
\hline Vitamin $\mathrm{B} 1$, thiamine & 1.50 & 0.10 & 6.55 \\
\hline $\begin{array}{l}\text { Vitamin } \mathrm{B} 2, \\
\text { riboflavin }\end{array}$ & 1.80 & 0.23 & 12.90 \\
\hline Vitamin B4, choline & 500.00 & 15.53 & 3.11 \\
\hline $\begin{array}{c}\text { Vitamin B5, } \\
\text { pantothenic acid }\end{array}$ & 5.00 & 0.18 & 3.70 \\
\hline $\begin{array}{l}\text { Vitamin B6, } \\
\text { pyridoxine }\end{array}$ & 2.00 & 0.04 & 1.76 \\
\hline Vitamin B9, folata & 0.04 & 0.01 & 35.74 \\
\hline $\begin{array}{c}\text { Vitamin } \mathrm{C} \text {, ascorbic } \\
\text { acid }\end{array}$ & 90.00 & 0.47 & 0.52 \\
\hline $\begin{array}{l}\text { Vitamin E, alpha } \\
\text { tocopherol }\end{array}$ & 15.00 & 0.80 & 5.35 \\
\hline $\begin{array}{l}\text { Vitamin K, } \\
\text { phyloquinone }\end{array}$ & 0.12 & 0.00 & 1.50 \\
\hline Vitamin PP & 20.00 & 2.82 & 14.10 \\
\hline \multicolumn{4}{|c|}{ Polyunsaturated fat acids } \\
\hline Linolenic & 1600.00 & 20.88 & 1.31 \\
\hline Linoleic & 10000.00 & 3603.54 & 36.04 \\
\hline
\end{tabular}
ACIDS COMPOSITION OF BISCUIT SEMI-FINISHED PRODUCTS 
Expediency of pumpkin seeds flour utilization in a biscuit semi-finished product technology was proved by investigation of its nutritional value (table VI) and mineral elements, vitamins and polyunsaturated fat acids composition (table VII).

\section{CONCLUSION}

Technological characteristics of pumpkin seeds flour were investigated, on the basis of which the studies were conducted by the main organoleptic and physicochemical indicators of biscuit semi-finished products with a complete substitution of wheat flour to pumpkin seeds flour with variation of the starch ratio.

It was established that the optimal ratio of pumpkin seeds flour and starch is $90.5 \pm 0.5 \%$ to $9.5 \pm 0.5 \%$.

Samples of biscuit semi-finished products baked with a separate addition of eggs surpassed the sample prepared with a traditional technology (with the use of mélange) by all quality indicators.

After consuming $100 \mathrm{~g}$ of the biscuit with a complete substitution of wheat flour to the gluten-free mixture $44.48 \%$ of daily need in magnesium, $49.56 \%$ - in selenium, $38.95 \%$ - in copper, $48.29 \%$ - in phosphorus, $46.40 \%$ - in manganese, $35.74 \%$ - in vitamin B9, and $36.04 \%$ - in linoleic acid is satisfied.

\section{References}

[1] A.S. Locmanov, G.I. Nazimova, A.S. Romanov "Beekeeping products utilization for enhancing the nutritional value of cakes" Techniques and technologies of food industries vol 3, pp.71-77, 2011

[2] M.O. Revnova "Allergic diseases and Gee's disease: mechanisms of contiguity and differences" Life without gluten vol 3, pp.4-63, 2006

[3] V.F. Docenko "Studies on possibility of fruit powder utilization in biscuit semi-finished products technology" East-European Magazine of Advanced technologies V. 3, vol 10 (69), pp. 64-69, 2014

[4] A.A. Lukin, S.P. Merenkova, T.U. Fomina "Development of technology and recipe for biscuit semi-finished products from bird cherry flour" Ypung scientist. vol 10, pp. 2663-266, 2016.

[5] T.V. Matveeva, S.Y. Koryachkina Flour confectionery of functional use. Scientific basis, technologies, recipes - Spb.: GIORD, 2016. $-360 \mathrm{p}$
[6] T.V. Matveeva "Pumpkin, carrot, and orange purees utilization in cupcakes technologies" Commodity researcher of Food Products. vol 7, pp. 17-21, 2009

[7] E.V. Moskvicheva, E.E. Safonova, I.A. Timoshenkova "Thistle seeds flour utilization in production of gluten-free products" International science and research magazine, vol 8-3(62), pp.46-50, 2017

[8] E.V. Moskvicheva, I.A. Timoshenkova, D.A. Chernikova "Development of technology and recipe of flour confectionery with the use of pumpkin conversion products" Week of science in SpbPU: material of scientific conference with international participation. Higher School of Biotechnology and Food Technologies. - Spb.: Edition of Polytechnic University, 2017 - pp. $95-98$

[9] O.V. Perfilova "Fruit anf vegetable powders from extracts in confectionery industry" Storing and recycling of agricultural materials. vol 9, pp.52-54, 2009

[10] Yu.G. Bazarnova, O.B. Ivanchenko Investigation of the composition of biologically active substances in extracts of wild plants, Voprosy Pitaniia, vol. 5, pp. 100-107, 2016

[11] Ji Y. "Staling of cake prepared from rice flour and sticky rice flour" Food Chemistry vol 100. pp. 53-58, 2007

[12] A. Sae-Eaw "Acceptance and purchase intent of US consumers for non wheat rice butter cakes" Journal of Food Science vol 72, pp. 92-97, 2007

[13] V.S. Popov, S.S. Sergeyeva, N.V. Barsukova "Functional and technological proper-ties of oat grain and a line of promising food products on its basis." Bulletin of the University of technology, Vol. 19, no. 16, pp. 147-151, 2016.

[14] I.A. Pankina, A.V. Barsukov "Investigation of the technological properties of the narrow-leaved lupine in order to create functional food products" A collection of articles III international scientific and practical Conference. Ekaterinburg, 2015, pp. 127-131.

[15] Collection of recipes of flour confectionery and bun products for public food enterprises. - M.: Economics, 1986. -295 p.

[16] Natalia Barsukova, Elena Moskvicheva, Irina Timoshenkova, "Evgeny Tsopa Informational technologies and the prospects of personalization of food rations" SHS Web of Conferences. Vol. 44, p.8, 2018

[17] J.E.R. Batista, L.P. Braga, R.C. de Oliveira, E.P. Silva, C. Damian "Partial replacement of wheat flour by pumpkin seed flour in the production of cupcakes filled with carob" Food Science and Technology vol. 38(2), pp. 250-254, 2018

[18] L.L. Costa, P.H.F. Tomé, F.B.B. Jardim, K.A. Damasceno, P.C.B. Campagnol "Physicochemical and rheological characterization of pan bread made with pumpkin seed flour" International Food Research Journal vol. 25(4), pp. 1489-1496, 2018 